\title{
Anthropology
}

\section{A Science of the Non-event?}

\author{
HAMISH MORGAN
}

Combined Universities Centre for RuRAL HEALth

Anthropology has been described, Ghassan Hage notes, as a 'science of the nonevent'. 'Some unkind people think anthropology itself is a non-event'. ${ }^{1}$ The argument goes that by studying the banal facts of everyday life (kinship, cross-cousin marriage, food distribution) anthropology foreclosed on the unexpected, the lateral; the eruption and passion of transformative events-and the contingencies involved therein-was (is?) left to the historians. ${ }^{2}$

I want to take a different approach; I want to think of ethnography as a science of the event. I want to be kind to anthropology. Can you imagine an ethnography where nothing happens? What would the anthropologist write about? What would nudge and agitate the anthropologist's writing if there were no events; if there were no events with others? What would enable the experience of community with others-which is the possibility of anthropological work-if there were no events that inspired, challenged and questioned one's practice; that pricked the skin and touched the intellect; that enveloped one in affective relations that transformed one's relation to the world? Where would ethnography be without the 
encounter, without 'contact' and 'proximity'? Where would it be without being touched and moved by another, without being tipped over into another paradigm, into another opening of the world? ${ }^{3}$ How could anthropology take place without being exposed to the work of others, of taking this as the work itself?

There is no ethnography without the event; it is the very stuff of ethnography. However, the problem is how to think the event. How to think the event without this being the occasion for ushering in all those tired and saturated anthropological notions that fence-in and explain the event (a ritual, a performance, a meeting, a gathering and so on) as if they were unmediated, objective signifiers that have the effect of "construct[ing] another society as unified, "over there" objective ... characterised by "certain distinctive beliefs"'.4 The problem is how to resist the description of the event as if it were a stable signifier of identity; as an objective reference for a communal essence that the ethnographer 'works out' and reveals. The problem is how to keep the surprise of the event working beyond a reduction to the self-same and secured presentation of knowledge. 5

The first part of this essay considers ways to draw upon the transformative potential of thinking the 'event'. I then use this to sketch the possibility of developing another kind of ethnographic writing attuned to the relation with others as the point of contact, contingency and communication. This I will conceptualise as writing 'community'. This has developed from my research work with Aboriginal people, especially the Jackman family, in central Western Australia.

\section{- 'TIPPING OVER INTO NEW PARADIGMS'}

I, along with many others, think of the event as an encounter between forces; an encounter that makes something happen. Hage points out that there is no 'crosssituational objectivity' in an event. ${ }^{6}$ What he means by this is that the event produces different effects on different people: it forces different responses. There is no absolute explanation possible, there is no objective point of view that could contain all possible meanings and effects. The event is what breaks-through, what cannot be foreseen or known in advance; the 'eventness' of the event is that it surprises and surpasses exhaustive explanation. It could be said then, that the event creates contingencies (the event is a contingency?). The event unleashes forces that 
cannot be planned for, nor absolutely controlled. Writing on contingency, Stephen Muecke comments that:

Contingency, in its Latin root, is about touching, bordering on, reaching, befalling. It is not therefore about maintaining critical distance, but about tipping over into new paradigms where encounters (with Others for instance) can teach us, not necessarily by direct instruction, but by putting our preconceived ideas in jeopardy. It is about not eliminating the risky or accidental. ${ }^{7}$

This is why I think the event, and the contingencies involved therein, is important to social theorists, because I think it is important to be 'tipped' towards 'new paradigms', it is important to stay with the (sometimes un-nameable) things that people show us and teach us; this becomes apparent in events. Events are the moments when one can stay with the contingent forces that touch. Sara Ahmed has a slightly different take on 'contingency'. She writes:

The word 'contingency' has the same root in Latin as the word 'contact' (Latin: contingere: com-, with; tangere, to touch). Contingency is linked then to proximity, to getting close enough to touch another and be moved by another. ${ }^{8}$

Contingency is about getting close enough to feel something happening, prior to determining what is happening. The privileged moment to stay with this befalling and contact is the event, where determination may be suspended and withheld. What the event produces is a force; an inclination towards others that resists being pinned down-a surprise that cannot be adequately accounted for. This is the sense of the event that I want to draw out.

What the event may open up is a gap or a tension between the explicable and the inexplicable, between the structure and the unusual moment that seems to overthrow a structural rationalisation. I want to stay with this tension, because I think it is important to the kind of work that ethnographers do; this tension, which is also a risk, offers a paradigm to understand what others teach us. This is what ethnography is all about, isn't it? Responding to and staying with what others make possible through the shared events of fieldwork, getting close enough to be moved by others beyond 'our' own frameworks of comprehension; making this the condition of writing and of ethnographic research. 
What I want to ask is: how do events with others (fieldwork) transform and make a difference to our understanding? Do we stay with this transformative potential or do we foreclose upon the work of others and the things 'they' produce by returning to a rational, codified and disciplined account built around, and for, the extraction of meaning and determination? Do we listen to events? I see potentiality in the event and in the work that others do to open up another way of seeing and being in the world. What is required is a little sensitivity, the suspension of determination, and trying to stay with the force of the event as a force that moves and touches. What we should be seeking in writing events is the befalling of one's self-same continuity with the world. Anthropology is in a privileged position to write this because anthropologists expose their work to the force of others. In fact, this is the event of anthropological possibility. The possibility of anthropological work is working the work of others as the work itself.

The point I want to make out of this, is that rather than thinking the event as reducible to 'the extraction of meaning', ${ }^{9}$ why not see it as a potential to transform thinking-for which a coherent or 'common sense' answer may not be possible? In this way I hope, following the anthropologist Michael Jackson's lead, to resist 'anthropology's proclivity to flatten out difference and contingency in order to promote an illusory authority'.10 Anthropologists may think this is an unfair characterisation of what is, after all, a complex and dynamic field; there are countless exceptions to the structural rules of anthropology, as the transformative work of Kathleen Stewart, Michael Jackson and Michael Taussig has shown.11 Yet, I still want to indicate that anthropological emphasis always tends to be on 'explanation' of an alternate social world, rather than on what we might call an ethical challenge to be transformed by it. But, more than this, anthropology is still very much about the illumination of 'wholes' - the illumination of the structuring of relations that give coherence to other worlds.

This reminds me, in an 'out of left field' kind of way, of the well-known but problematic distinction between the ethical (a relation with another) and the political (the relation with many others as a whole; that is, the structuring of relations). Anthropologists go for the structure, they work to describe 'wholes'; anthropological authority is established by gaining and speaking the 'commonsense' of the people. A political impetus perhaps (having the voice of the people?), 
rather than an ethical one. The strange thing here is that, unlike politicians, contemporary Australian ethnographers recognise that no 'bounded group' exists as such, but they nonetheless put it to work in the name of proper anthropological work. Hence, even in some of the most interesting Australian ethnographies we cannot get away from the claim: 'the Pintupi', 'for the Warlpiri', 'in Kukatja belief'-a pseudo-subject is called upon to stand for the whole, and this is used to appeal to a pseudo-unity.12 But this is not meant to be a critique of anthropology, rather my aim is to give a sense of the possibilities of the ethnographic event to challenge, disrupt and transform thinking. I want to keep an ear out for the otherwise, rather than an eye on the same: I have found 'contingency theory' and poststructuralist notion of the event useful in drawing this out, rather than 'proper' anthropological methods. (Following Hage, I see a 'good cultural studies kind of way' of thinking about ethnography - a way that 'tickles the imagination and the intellect'.) ${ }^{13}$ There is an 'unheard sense' that takes place and that happens when you spend time with others. ${ }^{14}$ It is this that I want to draw your attention to, and I oppose this necessarily, and perhaps unfairly, to anthropological models that seek to capture the meanings of 'other worlds'.

-BEING OUT OF TIME WITH THE EVENT

With this interest in the resistance to a complete and masterly account, and in the hope of creating a writing exposed to the outside, to difference, to resisting determination, I would like to turn (with my tongue in my cheek) to a rather strange essay written by Johannes Fabian and collected in his Time and the Work of Anthropology: Critical Essays 1971-1991. Fabian uses an anecdote in his essay, 'Of Dogs Alive, Birds Dead, and Time to Tell a Story', in order to discuss what he sees as the use of allochronic (literally: other-time) discourse and a denial of coevalness (sharing time) in ethnographic writing. ${ }^{15}$ This essay extends and draws upon his earlier work Time and the Other: How Anthropology Makes Its Object. Essentially, Time and the Other makes the argument that anthropological work constructs others as if they existed in another time; this is what Fabian calls allochronism. He writes that the 'conjuring trick' of anthropology is that it 'constructs the Other in terms of distance, spatial and temporal' this has the function 'to keep the Other outside the time of anthropology'. This 'petrified relation,' Fabian writes, 'is a scandal'.16 
I want to use the event he describes below, as a way to be re-surprised and to re-think what makes sharing time possible. What are we looking for by sharing time with others? Fabian writes:

Here, then, is the first story. Billie, our dog, is a White West Highland terrier of, I believe, striking and distinguished appearance. One day, my friend and I took her for a walk in the streets of Amsterdam. Billie was very young then and we kept her on one of those long leashes that come with a self-rewinding reel. We were walking and talking and did not pay much attention to Billie. We 'knew' she was trotting along happily. Suddenly my friend, who had been holding the leash, stopped. She turned around to look back. 'Look Johannes,' she said, 'there is a dog exactly like ours.' I looked and saw the dog. It took us a split second to realise that it was Billie, at the far end of her ten yards of freedom. ${ }^{17}$

I, too, would be at the end of my tether, trying desperately to get away from this event, much happier to explore the world away from the heels of anthropologyalways being linked to a pre-emptive phrase regime. ${ }^{18}$ Following lines of scent, following them until their intensity crescendos, moving on, finding the trace of others before me. Rambling rhizomically from intensity to intensity, but always dragged at the neck by this anthropologist and his auto-rewinding leash. This anthropologist and his friend, engrossed in thought, follow lines of articulation. Certain strata carry them away, take them off as they remember things; as they present these things to each other. Ideas building, being traced to a moment of intensity, they are being moved by the work of another. Then other lines take them off again, endlessly beginning and ending, sniffing out and marking territory as they go: retracing, crossing over, being taken off again. We are rambling. For a moment we forget ourselves, are in other places, engrossed in other thoughts that are not of the here and now, but of the before, and of the future, and of over there. I stop, look them in the eye, ears pricked at the end of my tether. They turn around: 'Look, Johannes, there is a dog exactly like ours.' They do not know me, themselves. My rambling world collapses. Ears limp, tail between my legs, I come, dragged back to where I'm called. 'Billie come here', in a straight line I come to heel, to the anthropologist, drawn on the self-rewinding leash. 
Sometimes it takes the honesty of a dog and the joy of her rambles to reveal the nature of an event. It is interesting to discuss how Fabian works this anecdote, how he unleashes it, so to speak. Fabian uses this anecdote to reveal, in a selfreflexive move, what happens in allochronic anthropological discourse. ${ }^{19}$ He argues that: 'Rather than experiencing our dog-and through her, us and the event-as being there as well as here we saw another dog'.20

Fabian corrects his misrecognition of Billie as other by arguing that sharing time is both here (Johannes and Friend) and there (Billie). He had seen Billie as other (and not the same) because she was there and he was here: the lesson here is that spatial separation may create a split-second reflex of othering, something that needs correction. Fabian attempts to resolve this by recognising the event as that which includes both here and there. 'Sameness,' Fabian writes, 'it would seem, requires or, if this is too strong a word, goes together with presence here, with sharing the same time as well as the same place as the one who considers identity.'21 This proposition, or more likely this presupposition, of 'sharing time' is 'bounded' (Fabian's term) in the 'event'. His conception of the event rests on a definition of the event as 'something that requires contemporaneous togetherness'. ${ }^{22}$ This is fine, but, contemporaneous togetherness does not mean presence or sameness, or that the event expresses these assumptions. Being together does not mean recognising the same; we don't spend time with others in order to receive sameness; we engage with others because they offer a different vision and relation to the world, and this touches us, moves us, impels us on. Isn't the whole idea of fieldwork to be taken out of one's self-same relation to the world? To have one's ideas, methods and assumptions pushed, challenged and transformed by the work of others? To not be able to return to one's writing unaltered by the events we share in common, and in difference, with others?

But, I want to say something more than this. Fabian uses the event to describe and play-out again his prior framework of understanding the ethnographic encounter; that is, his coeval model. It may not be a bad way to look at things, but the point I want to make is that the event becomes meaningful precisely at the point where his ethnographic model returns. Explanation of the event, its reduction to (its proper) meaning is secured by the dog returning to the master. The outward extension, the possibility of encountering something else-that tension which ties 
the same to the other-is resolved by the dog returning 'to the one who considers identity'. So what have we learnt? Simply, perhaps, that Fabian's coeval model, conceived in sameness and in bounded events, may be total and is just played-out in the same kind of ways in different places and contexts. Have model will travel, anywhere. What I am trying to do is to wonder whether we can be swept up in events in ways that mean you cannot simply find your feet, your model-or your dog on its leash - unaltered. This would imply untying the event from the demand of finding its common sense meaning.

You may well be thinking that this is nit picking, an overly close reading of a rather obscure moment in Fabian's oeuvre. But there is a chance in this reading to force the question: what are we looking for by doing ethnography? How do we relate to the events of fieldwork? Is it by standing back in a position of 'cross-situational objectivity'23 determining the meaning of the event-walking our readers through it-or should we make our work respond to 'the fragmentary structures of the "now" that the investigating subject inhabits',24 where no stable or unmediated position is possible, being tripped and tipped by the force of others-by their radical break with a continuity of the same? A position where one is thrown towards contact, touching, befalling; towards, this is what I am arguing, a relation with others that has the potential to transform ideas, methods and assumptions, at all points, without rest or recourse to already worked out ideas.

An event takes place because one's thoughts are placed in question. An explanation cannot be gathered together, it fails, reaches its limit, trips over the edge perhaps: one is put in question. How prepared are anthropologists to follow the lead of others, at what point do they yank it back to where they stand? How prepared are we to change our rhythm to that of another: 'When we walk, we set up a certain gait according to the intensity of our energy or our languor, but our stride or amble takes up the rhythm of the rocky or sandy ground and that of the waves against the beach. It catches on the pace of a companion'. ${ }^{25}$ The rhythm, the spacing, ${ }^{26}$ the ramblings of others, are they moments to stop, pull back, survey the scene; the other at her ten yards of freedom? Could we be taken along, open to the otherwise, listening, sentient to the happening? 
Keeping the moment of determination open allows an articulation of how others force another potential way of seeing and being in this world. This also entails another praxis of writing. A writing practice that is exposed to interruption, to fragments, to little events and encounters, this is what I try and perform below as a response to the above. The event that happens below does not synthesis the observations above, its just another chance to question and think again. But how to think of community?

Nancy in Being Singular Plural writes that, 'Not only are all people different but they are also different from one another. They do not differ from an archetype or a generality' ${ }^{27}$ An individual is singularly different: this is what we share in-common with others. Norris puts it nicely when he says that, 'what we have in common is precisely not a shared identity, but rather the "fact" that we are different from oneanother' and that we respond to the world differently. ${ }^{28}$ This implies that community (as being exposed to difference) has force that tips you into a relation with another where no self-secure position is possible; to be in-community is to necessarily be exposed to the work of others beyond a self-sufficient positioning. ${ }^{29}$ Nancy calls this an 'ontological sociality', that "my" face [is] always exposed to others, always turned toward an other and faced by him or her, never facing myself'. 30

What Nancy wants to think as a result, is the movement between one and another as such; he wants to think the relation as pivotal: the way a relation turns and moves one towards another-and not just towards human others, but also towards things in the world. ${ }^{31}$ In this way community can be thought of, as Secomb has noted, as 'an activity of interrelation'. ${ }^{32}$ This activity of interrelation it is not harmonised or completed in a common work or objective, but is rather shared out and shared again, working a space without 'hypostatisisation'. Community, again, is a spacing of relations, a spacing that 'provides incessant re-creation and dissimilarity'. ${ }^{33}$ Community is that happening tension that tugs and stretches us towards others. It is, in fact, because 'communion' or 'absolute identity' cannot take place that enables and energises-like a 'streaming of electricity' - communication with others. ${ }^{34}$ Community 'furnishes' this relation. ${ }^{35}$ Community, being-with-others, 
is the spacing of the singular plural relation that makes this happen. Needless to say there is no auto-rewinding leash here, only ecstatic movement.

My research work has been involved with an Aboriginal community in central Western Australia called Ululla. The Jackman family have stayed on and off at Ululla for the last twenty years. Ululla is not their traditional country. The Jackmans are a marginalised family in the broader community. Ululla has become a negotiated place to create a home, a place where a community can gather. Ululla was initially started by a man named Don Miller, who bought the lease to a sheep station with the idea of providing a place for teenagers to do their 'community service hours' as conditions of bail or to avoid custodial sentences; the Jackman family ended making Ululla a home. I initially lived in Ululla for two years before returning to Melbourne and beginning research.

What I want to do here is both banal and potentially radical at once; I want to stay with the happening of the event of community. ${ }^{36}$ I want to stay with the relation as the point of contact, contingency and difference; I want to force the relation into view as the basis for being-in-common. I want to think of the relation through the way it turns us towards another, and, as we will see, towards 'a space on the side of the road'. ${ }^{37}$ Community, a waiting, a waiting for the call of another who takes you off again; a readiness at hand to be taken towards others.

Yet, this work is not my own. When I would meet members of the Jackman family in Perth, in Meekatharra or in Wiluna (small remote towns near Ululla), we would talk mostly about other people; all the people we knew in common. We'd find out where people were, how they were going, where they're heading. We'd place ourselves and interact through gaining a sense of where others are. When I was speaking to people about Ululla and about being connected to others, about their experience of Ululla, at some point people would say, 'I don't know about that one, go and see Shelia or Sniper, he knows'. I'd go and see Shelia and she would say, 'you should see Rita (her sister), she's the first one that been there' (Ululla). I'd see Rita, and she would say, 'I haven't been there for a long time, I don't know about that one. Shelia was there at the time.' The great thing about research is that people may work over and deny your attempts to flesh out the community in a total fashion; there is always another relation, another point of contingency and of contact. The community constantly extending into other relations; relations that diffuse the 
possibility of settled and contained notion of community, there is always a relation that must be followed, this will lead onto others. ${ }^{38}$

How does community happen when people refuse to speak for another, people refusing the position of spokesperson, they refuse to conceptualise community in such a way that would provide a model or an experience that would represent all? There is no speaking for the community here-if you want to know about that then go and see that person-only the necessity to go with another relation. Another interruption takes hold. What this ethic does is force the relation as a movement towards others into view. It is an ethics, a spacing and rhythm of the relation as the basis for being in common. ${ }^{39}$ This ethic is very strong. Within this there is no foreclosure on the possibility of another happening; another rhythm, another spacing can take place; another relation is forced. ${ }^{40}$

\section{—GOING ROUND TO RITA'S HOUSE}

Time to tell a story. It's a story about going to Karalunidi to see Rita, with Molly and Sadie-all three sisters of the Jackman family who are all in their fifties. The story starts in Meekatharra. Molly and Sadie had moved from Ululla to Meekatharra earlier in the year (2007). This research event happens with my partner, Cath, and our then 9-month-old baby, Dusty. We had been camping in Meekatharra catching up with the 'Ululla mob'. 41

In the morning we (Cath, Dusty and I) went around to Rita's house, but she'd left and gone to Karalundi-a Seventh Day Adventist mission school fifty kilometres north of Meekatharra. I went round to Molly's house to see if she wanted to come 'for a ride'; she did, and Sadie came too. On the way Molly pointed out all the places she used to go to when she was at Karalundi as a kid. She did her schooling there (along with most of the Jackman family). Once she had finished school, she worked at Karalundi in a domestic capacity. Molly had told me about this the day before. She'd told me about all the hard work she had to do, 'I had to wash all the sheets on Tuesday and do all the uniforms on Thursdays,' she said it with a groan (remembering the work) and with a laugh (perhaps for the routine). Molly is pointing out all these places as we drive towards Karalundi, little markers on the side of the road that kick off memories and stories. There are 'breakaways' to the east that are 'full of goats' ${ }^{42}$ I'd thought she said 'ghosts' so I piped up and said what 
kind of 'ghosts'. 'Ahh, you know, those wild ones with big horns.' Really? I said, excitedly. She may have sensed I had the wrong idea: 'You know any kind of nannygoat.' Oh, I said, I thought you said 'ghosts'.

Sometimes your attention for the unexpected can be misguided, overworked. She pointed out where they were dropped off as kids, on the way to Karalundi and allowed to collect koglers (a kind of native pear that grows as a vine). Molly pointed out a 'back way' to Ululla through Moloogool, Diamond Well and Paroo stations'we did that once,' she added. She pointed out places where she had got emu eggs; this kicked off other stories about getting emu eggs at Ululla. That road to Karalundi, that Molly had travelled so many times, was full of stories, events and memories. She pointed out a cross on the side of the road surrounded by flowers. 'That was where my niece died, the rear gate on the mission truck had opened, she's fallen.' Molly hushed, became quiet. 'They got rid of the truck after that, got the bus.' Every couple of kilometres she would point out another story on the side of the road. We got to the gate at Karalundi mission. It was locked. I thought of gated communities.

I looked to Molly, we waited. 'That whitefella will come along,' said Molly. Sure enough, in a few moments, along comes a short man dressed in Cuban heels, ankle-hugging jeans, shirt and cowboy hat. Hardly what you'd expect from a Seventh Day Adventist-all those references to the romance of producing beef (Seventh Day Adventists are vegetarian). But I suppose most people are dressed in contradiction. This the boss coming now, says Molly. He dresses flash way, I said. He always dresses like that. I could imagine his boots crunching on the ground. Molly knew him and he her, they talked for a moment candidly. He asked me how he could help me, in a way that put me on my best behaviour. I explained that we'd come to visit Rita who was staying here with her daughter Deborah, who works here as a teacher's aide. He opened the gate while balancing his Cuban heels on the rather menacing cattle grid that stood gaping on the other side of the gate. We drove through, the cattle grid clunking, and he locked the gate behind us. Molly directed us to Deborah's house with her hand. As we drove around she pointed out all the buildings: 'That's the girl's dormitory, that's the boys, that's where I used to do the laundry.' 'Sheets on Tuesday and uniforms on Thursdays,' I said, cheekily. Molly laughed. That's where I used to cook, there's the farm, the orchid, all the teachers' houses. We pulled up at the house where Rita was staying and we were greeted on the veranda. 'Where you 
come from, Meeka (Meekatharra)?' Leonie asked. Leonie is Rita's daughter. 'Yeah. I heard you were coming, someone said you were asking for us at our house, but we came up here in the morning,' said Leonie. I'm not sure how word got here that we were coming but it had beaten us up the road. We sat on the veranda and Molly, Sadie and Rita gathered and dragged chairs together and sat talking, their limbs relaxing into the others', all looking into the space and light beyond the veranda. They were asking each other about family members, where they were and what they were up to. 'Sniper still there (in Meekatharra)?' 'No he left (for Wiluna) with Ginji [his daughter in-law].' 'She came from Newman in that Toyota.' 'Daniel?' 'No! Daniel never came [from Newman, another regional town],' said Sadie. Sadie said something about Daniel losing his key card (an 'eftpos' card) in the creek, but I only caught half of it.

They kept swapping news, asking questions, filling each other in on the family's happenings. Three sisters leaning into conversation with each other. Conversation slowed, Molly told Rita why we were here. But 'what am I going to say', said Rita, to her sisters. 'Just, wangka (talk) you know, anything,' said Molly. I suppose this was my moment, to interrupt. I addressed Rita and explained what I was doing and the kind of things I was hoping to talk about. 'Oh, yeah,' she said. We began. Rita's daughter Leonie joined in.

The conversation between Rita and Leonie centred on the early days at Ululla. Leonie was one of the first of the Jackman familiy to stay at Ululla, she did six months of community hours there (community begins as a place to do your hours!). Her family (her mother, sisters and brother) ended up following her, and making Ululla a home. Over time more of the Jackman family (including Molly and Sadie) went to Ululla and made a home. Leonie and Rita both give a strong sense that the community happens because of movement, because people come and go, stay for a while, and then come back again. As Rita says: 'Yeah, then we stayed on, right up, until just us lot were left there. I don't know, we use to go away and come back again ... Yeah, come and go. Stayed on there for awhile.'

But Ululla is also place of sadness, for Rita especially: 'Yeah, we all got used to it. [With sadness.] We stayed on and on, our boys from prison, come out and do their time there. We sit down with them ... I had a bad luck with my husband (he passed away), then I just ... moved out, too much memories. [She trails off.] Now and 
then I used to go back, but lately I never been back. I'll have to go back there later on,' she says with optimism.

Leonie adds that 'We are making plans to go back there, to live there. Not at the moment, later on.'

The conversation turned as Deborah (who is Rita's daughter, Leonie's sister) came home from work (she works at the Karalundi school). She came as she invariably does, with infectious energy and 'spunk' and we caught up on news. 'Where you heading what you been up to, this your wife and baby, hello Dusty,' said Deborah, all at once, in one breath, without pause. We caught up on all the news, conversation moved to the others we had in common. She was going to Canberra next week with the Karalundi kids on a trip, catching the midnight flight from Perth. Conversation turned back to Ululla, Don and Helen (his daughter). To Sniper, and Nicki Nicki and Daniel and Irene (Molly/Sadie/Rita's sister). By this time Sadie, Molly and Rita were sitting together again, their chairs in a little semi-circle, talking, catching up, little stories about things that have been happening, keeping track of all the family.

Molly indicated that she wanted to go. We said our goodbyes and drove back towards the gate. It was locked, Molly told me to try in that shop there (pointing to a building). I got the key, unlocked the gate as I balanced on the ferocious cattle grid, drove through, returned the key and then locked the gate. Quite the performance to get out of this bounded community. We headed back to Meekatharra. Halfway there I saw a goanna on the road, I called 'Bunka!' Molly said, 'Pull up, pull up!' We overshot it; I turned around, and slowly crept back north up the highway. We parked on the shoulder of the Great Northern Highway, it was silent, stretching off, on its own, into the distance. Molly told me to block the goanna on 'the other side'. She directed me, as Cath pointed out laughing, later, like a sheep dog. She loved these middle-aged women bossing me around. Molly motioned with her hand to walk towards the goanna, the goanna stopped; she told me, silently, to do the same. Molly grabbed a rock and flung it, she hit it, but it ran away madly scuttling across the road towards Sadie who was waiting with a big stick on the shoulder of the road. Sadie is quite a small woman, and this stick was more of a log, towering above her head. She brought it down but missed the goanna that went scuttling, clouds of dust following it back into the bush. Sadie in bursts of laugher. We all laughed. It would have been a 
fairly strange performance, an odd arrangement of relations and positions and objectives in the middle of a major highway where massive road-trains thunder by with awesome violence.

We got back in the car, turned around and drove south again. Molly had seen a kangaroo on the way to Karalundi that had been hit the night before, but that was still alive. She wanted to stop and put him to sleep. We came across the kangaroo. Three roos had been on the road at night, two were dead, and one was still alive, her head 'sitting up'. Her body resting on one good leg, the other broken in awful fragments, hanging by sinews. You could see where she'd been knocked by the truck; you could see the drag marks as she clawed her way off the shoulder of the road and towards the bush. She was panting, in pain, distressed. Poor thing. Molly said I had to kill it. I tried to resist, can't you, I pleaded. No you must. She told me how to kill it. The event happened, we drove on. We were back in Meekatharra in a moment. We dropped Sadie and Molly back at their place. I started to try and write about the events of community.

If we are to write community, then what we need to do is to stay with the happening of community. To write community is to not be able to find a position outside the happening of community, its relations and spacings and objectives. So when you speak about it, you are thrown into it and cannot stand back from this force. The multiple, the singular events, irrupt and are forced into view, you go and comeback again, leaving and returning-that sense of movement. Isn't this part of what Rita was saying? That she can't stand back, that there is still too much pain. That one cannot be objective in relation to community. To think of a place she called home and that held her family is to be thrown into the still-too-present force of the relation, the force of the relation (that still moves) is still happening. When people would say, 'I don't know about that one, go and see Shelia or Sniper', although in a very different way, doesn't this ethic do the same? It forces the following of the relation; it negates the possibility of standing back from the community itself. You are directed to 'follow up' another. Wasn't the same thing going on with the car trip, events being forced into view? That the happening was still there, still had force; that it articulated something. The ethnographer is thrown into and towards the force of events shared with others. You are directed, shown (sometimes ordered like 
a sheep dog), exposed to other happenings, sites of activity. Events jump up and take you off.

There is always a relation, there is always a chair pivoting on its leg, being directed to face another, to sit down with another and offer up what you know of the goings on of the world. One does not face oneself in community, one is turned towards others, their work, a kind of extension outward. ${ }^{43}$ Another story takes off. This is the imperative of community-the sharing of singularity, the sharing of difference as the site of being in common, as Nancy might say. And it is what Molly, Sadie and Rita showed me one day when we went to Karalundi, it was an oblique offering-it came from the 'side of the road' and interrupted the monotonous drone of a vehicle that may have otherwise been hell bent on reaching its objective, hell bent on setting the story straight (of community) without hesitation; without sensibility to all the things spilling out and into conversation, coming from the side, taking us off. An account that was forced to follow the lead of others as the condition for being together, as the condition of an ethnographic event.

Hamish Morgan has recently moved to the small Aboriginal community of Ululla with his young family to live more fully, to be more connected. He works part-time with the Combined Universities Centre for Rural Health in Geraldton on a number of cross-cultural exchange projects for students and academic staff in and around Wiluna. He was awarded his PhD from UTS's Trans/forming Cultures Centre in 2008. He also runs a small consultancy business called Narrative Connections.

\footnotetext{
-NOTES

1 Ghassan Hage, 'There is Nothing Here: Notes on Diasporic Ontologies', transcribed and edited P. Van Der Merwe, Antithesis, vol. 16, 2006, pp. 5-11, p. 5.

2 Hage, p. 5. Hage also wants to question why 'the event' is often linked to 'contingency', why it is often 'opposed to structure ... opposed to continuity', p. 6. The way I think of the event here is through contingency. I would direct you to Hage's article in order to consider his different thinking of the event.
} 
${ }^{3}$ Stephen Muecke, 'Contingency Theory: The Madagascan Experiment', interventions, vol. 6, no. 2, 2004, pp. 201-15.

${ }^{4}$ Muecke, p. 205.

${ }^{5}$ Lyotard is perhaps the pre-eminent thinker of the event. Lyotard's reading of events becomes one way, as Bill Reading comments, to resist 'the rule of the concept', a way to resist the reduction of the complex flows of social life to 'the extraction of meaning'. Bill Reading, Introducing Lyotard: Arts and Politics, Routledge, London, 1991, both quotes p. xiv. According to Lyotard there is resistance to an absolute, exhaustive comprehension in the event, this is so because the event disturbs or transforms prior frameworks of comprehension: there is a remainder, there is a 'drift', there is something different in the event that exceeds absolute contextualisation. There are contingencies that can't be managed. There is something unheard in the event that Lyotard wants to stay with. He writes in Peregrinations: 'To become sensitive to their quality as actual events, to become competent in listening to their sound underneath silence or noise, to become open to the "It happens that" rather than to the "What happens" [of the event]', Peregrinations: Law, Form, Event, Colombia University Press, New York, 1988, p. 18. Events happen, the problem is how to listen to the happening, to the it's happening of the event-to the uncertain moment 'when we realise our moral or political frameworks cannot account for some new problem with which we are faced'. Ashley Woodwood, 'Answering the Question, "What is an Event?"', Antithesis, vol. 16, 2006, p. 22.

6 Hage, p. 6.

7 Muecke, p. 203.

${ }^{8}$ Sara Ahmed, 'Collective Feelings, Or The Impressions Left By Others', Theory, Culture \& Society, vol. 21, no. 2, 2004, p. 27.

${ }^{9}$ Reading, p. xvi.

${ }^{10}$ Michael Jackson, Minima Ethnographica: Intersubjectivity and the Anthropological Project, University of Chicago Press, Chicago, 1998, p. 33.

11 Their work is transformative precisely because they try to imagine a different kind of ethnographic practice; this has been called 'new ethnography'. Kathleen Stewart describes this practice as one of, 'displacing the rigid discipline of "subject" and "object" that sets Us apart and leaves Them inert and without agency. It would mean displacing the premature urge to classify, code, contextualise, and name long enough to imagine something of the texture and density of spaces of desire that proliferate in Othered places'. A Space on the Side of the Road: Cultural Poetics in an 'Other' America, Princeton University Press, Princeton, 1996, p. 26.

12 I am referring to Fred R. Myers, Pintupi Country, Pintupi Self: Sentiment, Place and Politics Among Western Desert Aborigines, Smithsonian Institute, Washington, 1986; Francois Dussart, The Politics of Ritual in an Aboriginal Settlement: Kinship, Gender, and the Currency of Knowledge, Smithsonian Institution Press Washington, 2000 and Sylvia Poirier, $A$ World of Relationships: Itineraries, Dreams and Events in the Australian Western Desert, University of Toronto Press, Toronto, 2005. To use one 
example, while Myers, in his work Pintupi Country, Pintupi Self, recognises at a number of points, that there is no clear concept of 'Pintupi' as a bounded group he nonetheless uses it as a general conceptual category. It is worth quoting Myers here. 'Even their name is an artifact opposed on them by changing conditions. Though known in the area where they came to live as "Pintupi", most say they never used this label to refer to themselves before contact with whites ... the people called the Pintupi do not represent a single social entity, neither as a tribe nor a language group', p. 28. On the one hand he recognises that there is no 'Pintupi' as such, yet, on the other hand he nonetheless 'puts it to work'. This signals that the coherence of the anthropological object of study lies in considering others as if they constituted a proper group. Eric Michaels in his critique of Myers's book has also commented on this, see his chapter, 'If “All Anthropologists are Liars..."', in Eric Michaels, Bad Aboriginal Art: Tradition, Media and Technological Horizons, University of Michigan Press, Minneapolis, 1994, pp. 129-30.

13 Ghassan Hage, 'On “Having” Ethnography: Mimic Me ... If You Can', The Australian Journal of Anthropology, vol. 9, no. 3, 1998, p. 286.

${ }^{14}$ Jean-Luc Nancy 'You Ask Me What it Means Today: An Epigraph for Paragraph', Paragraph, vol. 16, no. 2, 1993, pp. 108-10.

${ }^{15} J o h a n n e s$ Fabian, 'Of Dogs Alive, Birds Dead, and Time to Tell a Story' in Johannes Fabian, Time and the Work of Anthropology: Critical Essays 1971-1991, Harwood Academic Publishers, Chur, Switzeland, 1991, pp. 225-44.

16 Johannes Fabian, Time and the Other: How Anthropology Makes Its Object, Colombia University Press, New York, 1983, p. xi, p. 143.

17 Fabian, 'Of Dogs Alive', p. 228.

18 Jean-Francois Lyotard, The Differend: Phrases in Dispute, trans. G. Van Den Abbeele, Manchester University Press, Manchester, 1988.

19 Fabian, 'Of Dogs Alive', p. 228.

${ }^{20}$ Fabian, 'Of Dogs Alive', p. 229.

21 Fabian, 'Of Dogs Alive', p. 229.

22 Fabian, 'Of Dogs Alive', p. 229.

${ }^{23}$ Hage observes that: 'We cannot give it [the event] some kind of cross-situational objectivity', p. 6. There is only a perspective, and that cannot be total. I am implying here that anthropologists take a position of cross-situational mastery in order to explain events, while indebted to Hage here, he does not say this as such.

24 Muecke, p. 208.

${ }^{25}$ Alphonso Lingis, The First Person Singular, Northwestern University Press, Evanston, 2007, p. 13.

${ }^{26}$ Jean-Luc Nancy, The Inoperative Community, P. Connor, trans. P. Connor, L. Garbus, M. Holland and S. Sawhney (eds), University of Minnesota Press, Minneapolis, 1991. 
27 Jean-Luc Nancy, Being Singular Plural, trans. R.D. Richardson and A.E. O’Byrne, Stanford University Press, Stanford, 2000, p. 8.

${ }^{28}$ Andrew Norris, 'Jean-Luc Nancy and the Myth of the Common', Constellations, vol. 7, no. 2, 2000, pp. 272-95, p. 273.

29 The best-known practitioner of this kind of ethnographic practice is Deborah Bird Rose. She sees the ethnographic research process as making a claim on one's position-it makes one responsible towards others, and this happens because the ethnographer is in relation with others. What I would argue here is that this relation is one of sharing difference in common. For the most succinct (and earliest) outline of this, see her, 'The Saga of Captain Cook: Morality in Aboriginal and European Law', Australian Aboriginal Studies, vol. 2, 1984, 24-39.

30 Nancy, The Inoperative Community, p. 28, p. xxxvii.

31 Nancy emphasises this in Being Singular Plural, see also his Listening, trans. C. Mandell, Fordham University Press, New York, 2007.

32 Linnell Secomb, 'Fractured Community', Hypatia, vol. 15, no. 2, 2000, pp. 133-50, p. 140.

33 Jean Luc Nancy, 'Interview: The Future of Philosophy', in B.C. Hutchens, Jean-Luc Nancy and the Future of Philosophy, Acumen, Chesham, 2005, p. 164.

${ }^{34}$ Georges Bataille, Inner Experience, trans. L. Bolt, State University of New York Press, Albany, 1988, p. 94.

35 Nancy, The Inoperative Community, p. 18.

36 Nancy writes: 'It [community] is rather a being-in-common which only happens, or which is happening, an event more than a "being”'. Jean-Luc Nancy, 'Finite History', in David Carrol (ed.), The States of "Theory": History, Art and Discourse, Colombia University Press, New York, 1990, p. 149.

37 Kathleen Stewart uses 'a space on the side of the road' as a metaphor that direct us to those spaces created as 'other' by dominant narratives of progress, 'order' and the American dream. She wants to listen to an 'incessant narrativization of a cultural real' of an 'Other America'. Stewart, p. 1.

38 Many anthropologists working in Australia have noted the extensive, regional nature of Western and Central Desert Aboriginal relationships. Fred Myers argues that what is valued above all in Pintupi society is overall regional relatedness; thus extensive and inclusive social ties organise Pintupi society, rather than distinct and bounded grouping (around country, partri-lines or sub-sections) p. 294. 'In the absence of boundaries', Myers writes, working towards his conclusion, 'in the Pintupi view they "are all family", and relatedness is not achieved through the integration of units as much as through the relation of all to all', p. 296. Myers calls this an 'open system of relatedness'. Myers points out that for the Pintupi the relation with another is vital, 'to be open to the claims by others' is an ethical imperative that cannot be declined, p. 22, see also pp. 15-21. This is also a significant part of Rose's and Poirier's work. See Deborah Bird Rose, Dingo Makes Us Human: Life and Land in Australian Aboriginal Culture, Cambridge University Press, Cambridge, 1992. See also Poirier, A World of Relationships.

39 Nancy, The Inoperative Community, p. 18. 
40 Basil Sansom has used the idea of 'happenings' to describe events in the fringe camps of Darwin. Here, the camp bosses, what Sansom calls 'Masterful Men', work to attract countrymen to their camps in order to secure custom, prestige and 'good time spending', p. 7-8. In short, to make the camp the place where it all happens. The Camp At Wallaby Cross: Aboriginal Fringe Dwellers in Darwin, Australian Institute of Aboriginal Studies Press, Canberra, 1980.

41 The following story is one I wrote after it happened. I have included quotation marks to Molly's speech only when a word for word transcription was possible. I have not placed in quotation marks speech that I remembered in the sense and style of her speech.

42 'Breakaways' are a significant feature of the landscape in this part of Western Australia. Breakaways are like cliff lines that erupt from the otherwise flat plane (usually formed at the head of ephemeral creeks). They are the colour of burnt orange and are spectacular places up close and from afar.

${ }^{43}$ Nancy, The Inoperative Community, p. xxxvii. 